\title{
Pengaruh Kompos Rumput Laut dan Azolla terhadap Pertumbuhan dan Hasil Bawang Merah
}

\section{Effect of Seaweed and Azolla Compost on the growth and yield of shallots}

\author{
Puguh Bintang Pamungkas, Okti Purwaningsih), Herman Budi Susetyo \\ Program Studi Agroteknologi, Fakultas Pertanian, Universitas PGRI \\ Jalan PGRI 1 Sonosewu No. 117 Yogyakarta (55182), Indonesia \\ *Penulis untuk korespondensi Email: okti_purwaningsih@yahoo.com
}

\begin{abstract}
Shallots are a horticultural commodity that is consumed by many people, but its availability is still insufficient domestic, so it must be met from imports. One way that can be done to increase production is the use of organic substances, which can meet the nutrient of shallots without a negative impact on the environment. The organic substances used are Azolla compost and seaweed, where seaweed contains auxin, cytokines, ethylene, and gibberellins, while Azolla contains $N, P$, $\mathrm{K}, \mathrm{Ca}$, and $\mathrm{Mg}$. This study aims to assess the agronomic characters of shallots to organic substances. The study was conducted February-July 2019 in Glondong, Purwobinangun, Pakem, Sleman DIY, the altitude of 600 meters above sea level. The type of soil used in the study is Regusol. Location research has the average rainfall is $125.8 \mathrm{~mm}$, the average temperature of $25.2^{\circ} \mathrm{C}$, the humidity of $78.2 \%$, and solar radiation 7.5 hours. The study used a completely randomized design of 2 factors (seaweed and Azolla compost) and 3 replications. The observed variables in terms of height $(\mathrm{cm})$, the rate of plant height $(\mathrm{cm} /$ week), number of leaves (leaf), the growth rate of leaves (leaf/week), the number of tubers (clump), the diameter of the bulbs (cm), fresh weight tuber (g), and harvest index (\%).The results of the study showed that the growth variable Seaweed Compost 1000 ppm+Without Azolla gives good results when compared with other treatments. For the yield variable, although there were no significant differences in the number and weight of tubers, the harvest index showed a significant difference.
\end{abstract}

Keywords: Azolla compost, seaweed, shallot

\section{INTISARI}

Bawang merah merupakan komoditas hortikultura yang banyak dikonsumsi masyarakat, namun ketersediaanya masih belum mencukupi kebutuhan dalam negeri, sehingga harus dipenuhi dari impor. Salah satu cara yang dapat dilakukan untuk meningkatkan produksinya adalah penggunaan bahan organik yang dapat memenuhi kebutuhan hara tanaman bawang merah tanpa memberikan dampak negatif bagi lingkungan sekitar. Bahan organik yang digunakan adalah kompos Azolla dan rumput laut, dimana rumput laut laut mengandung auksin, sitokinin, etilen, asam absisat, dan giberelin, sedangkan Azolla memiliki kandungan N, P, K, Ca dan Mg. Penelitian ini bertujuan untuk mengkaji karakter agronomis tanaman bawang merah terhadap pemberian bahan 
organik. Penelitian dilaksanakan pada bulan Februari-Juli 2019 di Dusun Glondong, Purwobinangun, Pakem, Sleman DIY, ketinggian tempat $600 \mathrm{mdpl}$. Jenis tanah yang digunakan dalam penelitian adalah tanah Regusol. Lokasi penelitian mempunyai curah hujan rata-rata $125,8 \mathrm{~mm}$, temperatur rata-rata $25,2^{\circ} \mathrm{C}$, kelembaban rata-rata $78,2 \%$, dan lama penyinaran matahari 7,5 jam. Penilitian menggunakan rancangan acak lengkap 2 faktor (rumput laut dan kompos Azolla) dan 3 ulangan. Variabel yang diamati meliputi tinggi tanaman (cm), laju tinggi tanaman ( $\mathrm{cm} / \mathrm{minggu}$ ), jumlah daun (helai), laju pertumbuhan daun (helai/minggu), jumlah umbi (rumpun), diameter umbi (cm), bobot segar umbi $(\mathrm{g})$, dan indeks panen (\%). Hasil penelitian pada variabel pertumbuhan menunjukkan bahwa perlakuan Rumput Laut 1000 ppm+Tanpa Kompos Azolla memberikan hasil yang cukup baik jika dibandingkan dengan perlakuan lainnya. Untuk variabel hasil, walaupun tidak ada perbedaan yang nyata dalam jumlah dan bobot umbi, namun untuk indeks panen menunjukkan perbedaan yang cukup signifikan.

Kata kunci: bawang merah, kompos Azolla, rumput laut

\section{PENDAHULUAN}

Bawang merah merupakan tanaman hortikultura yang dimanfaatkan sebagai bumbu masakan oleh masyarakat, selain itu dapat digunakan juga untuk kesehatan. Manfaat bawang merah untuk kesehatan antara lain adalah mengatasi sembelit, melegakan tenggorokan, mengontrol diabetes, menyehatkan jantung, menjaga tingkat kolesterol, detoksifikasi, mencegah perkembangan sel kanker, meningkatkan kesehatan otak, meningkatkan kesehatan tulang, meningkatkan imunitas (Anonim, 2018).

Hasil proyeksi konsumsi nasional bawangmerah tahun 2017 sampai 2021 diperkirakan naik 4,92\% per tahun. Konsumsi nasional tahun 2017 diproyeksikan sebesar 725.438 ton atau turun $0,77 \%$ dibandingkan tahun 2016. Pada tahun 2018 sampai 2021 konsumsi bawang merah diperkirakan akan naik, bahkan pada tahun 2021 konsumsi bawang merah diperkirakan mencapai 876.479 ton (Susanti dkk., 2017).

Berdasarkan proyeksi diatas, bisa dikatakan bahwa peluang pengembangan bawang merah di Indonesia sangat terbuka lebar. Namun praktek yang dilakukan petani dalam mendukung pengembangan tersebut sering menggunakan pupuk anorganik, seperti pupuk NPK mutiara, pupuk $\mathrm{KCl}$, pupuk SP36, pupuk ZA, pupuk urea.

Pemberian pupuk anorganik dapat memberikan damapak positif terhadap petani dalam hal meningkatkan produksi bawang merah petani, namun di sisi lain pupuk anorganik juga dapat memberikan dampak negatif kepada lingkungan dan manusia, 
seperti menyebabkan tanah menjadi masam dan padat sehingga kesuburan tanah berkurang, terjadinya pencemaran air, akumulasi bahan kimia dalam produk pertanian dapat mengganggu kesehatan manusia (Samadi dan Cahyono, 2005).

Untuk mengurangi resiko penggunaan pupuk anorganikmaka dapat digantikan dengan pemberian bahan organik maupun pupuk organik. Pemberian pupuk organik bisa dilakukan secara bertahap, dikombinasikan dengan pupuk anorganik atau $100 \%$ bahan organik tanpa pupuk anorganik. Bahan organik di alam tersedia dalam jumlah dan jenis yang sangat banyak. Seresah tanaman, kotoran hewan, limbah pabrik gula dan limbah rumah tangga dapat digunakan sebagai sumber bahan organik. Tanaman yang mudah terdekomposisi juga dapat digunakan sebagai sumber bahan organik. Salah satu tumbuhan yang dapat digunakan sebagai bahan organik adalah rumput laut dan Azolla.

Produksi rumput laut di Indonesia yang melimpah, telah dimanfaatkan sebagai produk olahan minuman maupun makanan, namun belum banyak digunakan dalam budidaya tanaman sebagai pupuk maupun sumber bahan organik. Disamping dapat dimanfaatkan sebagai bahan pangan, rumput laut laut juga dapat digunakan sebagai pupuk hayati karena mengandung auksin, sitokinin, etilen, asam absisat, dan giberelin serta mengandung trace mineral $\mathrm{Fe}, \mathrm{B}, \mathrm{Ca}, \mathrm{Cu}, \mathrm{Cl}, \mathrm{K}, \mathrm{Mg}$, dan $\mathrm{Mn}$ (Basmal, 2009). Walaupun demikian pemanfaatan rumput laut sebagai pupuk organik atau sumber bahan organik dalam usaha tani tanaman bawang merah belum banyak dilakukan. Oleh karena itu perlu dilakukan pengkajian respon tanaman bawang merah terhadap pemberian rumput laut.

Azolla diketahui mempunyai kandungan $\mathrm{N}$ yang tinggi sebesar 5-6\%, kandungan $\mathrm{P} 0,5-0,9 \%$, kandungan $\mathrm{K} 2-4 \%$, kandungan $\mathrm{Ca} 1 \%$, dan kandungan $\mathrm{Mg}$ 0,5\%. Penggunaan Azolla pada pertanaman bawang merah dapat menurunkan penggunaan pupuk anorganik sebesar 43\% dari anjuran (Rokhminarsi dkk., 2019), selain itu juga dapat meningkatkan ketersediaan dan serapan hara fosfat, berat umbi bawang merah dan hasil tanaman bawang merah (Begananda dkk., 2017; Suryanto, 2017).

Kombinasi perlakuan kompos Azolla dan rumput laut diharapkan dapat saling melengkapi pemenuhan kebutuhan hara makro karena rendahnya kandungan $\mathrm{N}$ pada rumput laut dapat dipenuhi dari kompos Azolla yang mengandung unsur hara N.Penelitian ini bertujuan untuk mengkaji karakter agronomis (tinggi tanaman, laju tinggi tanaman, jumlah daun, laju pertumbuhan daun, jumlah umbi, diameter umbi, 
bobot segar umbi, indeks panen) dari tanaman bawang merah terhadap pemberian bahan organik (rumput laut dan kompos Azolla).

\section{BAHAN DAN METODE}

Penelitian dilaksanakan pada bulan Februari-Juli 2019 di Dusun Glondong, Purwobinangun, Pakem, Sleman DIY, ketinggian tempat $600 \mathrm{mdpl}$. Jenis tanah yang digunakan dalam penelitian adalah tanah Regosol. Lokasi penelitian mempunyai kondisi klimatologis curah hujan rata-rata $125,8 \mathrm{~mm}$, temperatur rata-rata $25,2^{\circ} \mathrm{C}$, kelembaban rata-rata $78,2 \%$, dan lama penyinaran matahari 7,5 jam. Bahan-bahan yang digunakan adalah benih bawang merah varietas Tajuk, ekstrak rumput laut, komposAzolla.

Penelitian disusun dalam rancangan acak lengkap (Complete Randomized Design) dalam tiga ulangan dan terdiri atas dua faktor. Faktor pertama adalah pemberian rumput laut, terdiri atas tiga aras yaitutanpa rumput laut, pemberian rumput laut 1000 ppm, dan rumput laut 2000 ppm. Faktor kedua adalah pemberian kompos Azolla, terdiri atas dua aras yaitu tanpa kompos Azolla dan pemberian kompos Azolla.

Pengamatan dilakukan terhadap variabel agronomis yaitu tinggi tanaman, pengukuran menggunakan mistar, satuan pengukuran dalam $\mathrm{cm}$, diamati secara periodik satu minggu sekali untuk menghitung laju pertumbuhan tinggi tanaman; laju pertumbuhan tinggi tanaman; jumlah daun; laju pertumbuhan daun; jumlah umbi; diameter umbi, diukur menggunakan jangka sorong, hasil pengukuran dinyatakan dalam cm; bobot segar umbi; ditimbang menggunakan timbangan digital dan dinyatakan dalam gram indeks panen). Laju pertumbuhan tinggi tanaman diukur pada kisaran umur 1-9 minggu setelah tanam dan dihitung menggunakan rumus:

$$
\begin{aligned}
& b=\frac{n \sum X i Y i-\left(\sum X i\right)\left(\sum Y i\right)}{n \sum X i^{2}-\left(\sum X i\right)^{2}} \\
& b=\text { laju pertumbuhan tinggi tanaman. } \\
& X=\text { umur tanaman. } \\
& Y=\text { tinggi tanaman. }
\end{aligned}
$$

Laju pertumbuhan daun juga dihitung menggunakan rumus tersebut. Pengukuran indeks panen menggunakan rumus sebagai berikut:

$$
\begin{gathered}
\text { Indeks panen = }- \text { Bobot umbi } \\
\text { Bobot kering tanaman }
\end{gathered}
$$


Data hasil pengamatan dianalisis menggunakan Analysis of Variance pada jenjang nyata $5 \%$. Untuk mengetahui beda nyata antar perlakuan dilakukan melalui uji DMRT (Duncan Multiple Range Test).

\section{HASIL DAN PEMBAHASAN}

\section{Tinggi Tanaman dan Laju Tinggi Tanaman}

Dari hasil analisa sidik ragam, pemberian bahan organik rumput laut dan Azolla menunjukkan interaksi serta memberikan pengaruh yang nyata terhadap pertumbuhan tinggi tanaman bawang merah. Dapat dilihat bahwa nilai terbesar rerata tinggi bawang merah terdapat pada perlakuan Rumput Laut 1000ppm + Tanpa Kompos Azolla dan terendah ada pada perlakuan Tanpa Rumput Laut + Tanpa Kompos Azolla (Gambar 1 dan Tabel 1).

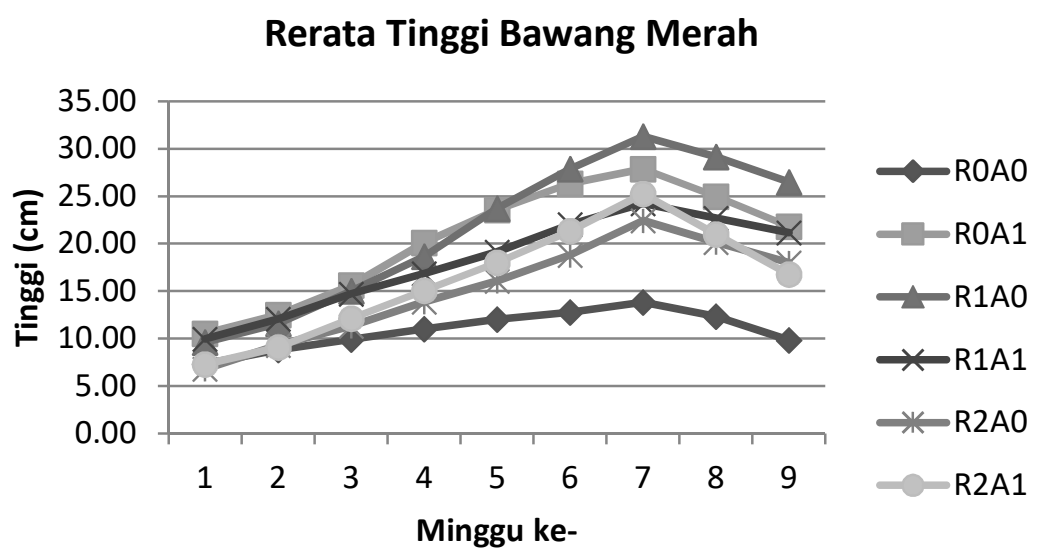

Gambar 1. Rerata tinggi bawang merah setelah diberi perlakuan pemberian bahan organik (rumput laut dan kompos Azolla).

Hasil analisis sidik ragam terhadap laju pertumbuhan tinggi tanaman menunjukkan adanya interaksi antar arumput laut dan Azolla terhadap laju pertumbuhan tinggi tanaman (Tabel 1). 
Tabel 1. Rerata laju tinggi bawang merah $(\mathrm{cm} / \mathrm{minggu})$ setelah diberi perlakuan pemberian bahan organik (rumput laut dan kompos Azolla).

\begin{tabular}{lc}
\hline \multicolumn{1}{c}{ Perlakuan } & Rerata \\
\hline Rumput Laut 1000ppm + Tanpa Kompos Azolla & $0,149 \mathrm{a}$ \\
Tanpa Rumput Laut + Kompos Azolla & $0,104 \mathrm{~b}$ \\
Rumput Laut 2000ppm + Kompos Azolla & $0,098 \mathrm{~b}$ \\
Rumput Laut 2000ppm + Tanpa Kompos Azolla & $0,096 \mathrm{~b}$ \\
Rumput Laut 1000ppm + Kompos Azolla & $0,093 \mathrm{~b}$ \\
Tanpa Rumput Laut + Tanpa Kompos Azolla & $0,046 \mathrm{c}$ \\
\hline
\end{tabular}

Keterangan: Nilai Rerata yang diikuti huruf yang sama pada kolom yang sama menunjukkan tidak berbeda nyata menurut DMRT $5 \%$.

Dari hasil analisis, interaksi antara bahan organik memberikan laju pertumbuhan tanaman tertinggi dibandingankan perlakuan yang lainnya dan hasil terendah ada pada perlakuan tanpa bahan organik.

Bahan organik yang diberikan dalam penelitian ini adalah rumput laut dan kompos Azolla. Pemberian bahan organik pada tanah berperan pentingdalam memperbaiki struktur tanah sehingga aerasiudara dan pergerakan air lancar, dengan demikiandapat menambah daya serap air dalam tanah danmampu meningkatkan pertumbuhan dan produksitanaman (Widawati dkk., 2002), selain itu disebabkan juga oleh rumput laut laut yang mengandung auksin, sitokinin, etilen, asam absisat, dan giberelin serta mengandung trace mineral $\mathrm{Fe}, \mathrm{B}, \mathrm{Ca}, \mathrm{Cu}, \mathrm{Cl}, \mathrm{K}, \mathrm{Mg}$, dan $\mathrm{Mn}$ (Basmal, 2009) yang dapat merangsang pertumbuhan tanaman.

Unsur Fosfor $(P)$ dalam bahan organik juga berperan dalam pembelahan dan perbanyakan sel sehingga tinggi tanaman dapat meningkat. Fosfor juga berperan mendorong pertumbuhan akar tanaman sehingga meningkatkan penyerapan hara $P$ pada tanaman. Peningkatan penyerapan $\mathrm{P}$ pada tanaman dapat meningkatkan pertumbuhan tinggi tanaman. Havlin dkk. (2005) menyatakan $P$ berperan dalam pembetukan inti sel, pembelahan, perbanyakan sel sedangkam menurut Rosmarkam dan Yuwono, (2002) P dapat mendorong pertumbuhan akar tanaman. 


\section{Jumlah Daun}

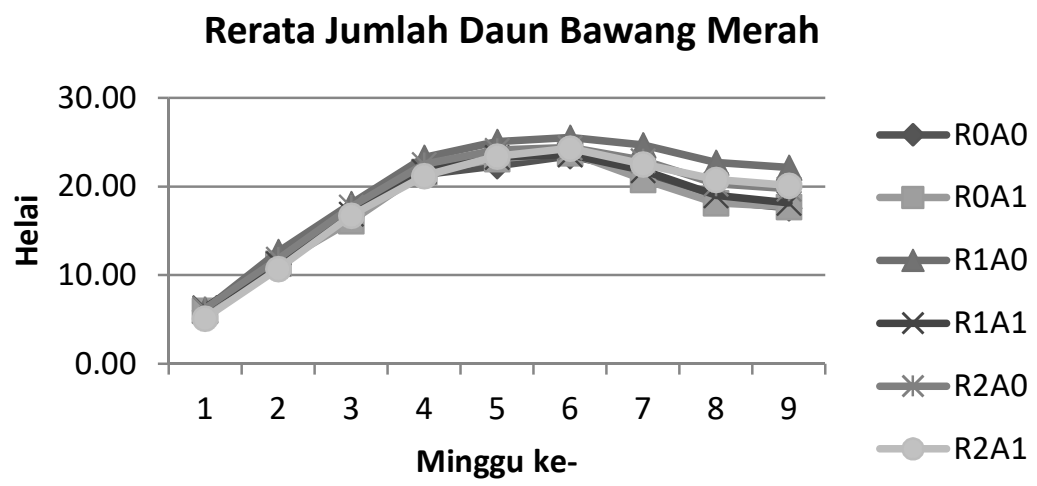

Gambar 2. Rerata jumlah daun bawang merah setelah diberi perlakuan pemberian bahan organik (rumput laut dan kompos Azolla).

Dari hasil penelitian pemberian pupuk organik menunjukkan tren positif, dimana perlakuan menunjukkan pengaruh yang nyata dibandingkan dengan kontrol. Dapat dilihat bahwa perlakuan Rumput Laut 1000ppm + Tanpa Kompos Azollamenunjukkan jumlah daun terbanyak, dan jumlah daun terendah adalah perlakuan Tanpa Rumput Laut + Tanpa Kompos Azolla.Latarang dan Syakur (2006) menyatakan bahwa pembentukan daun sangat dipengaruhi oleh jumlah, ukuran sel dan juga oleh unsur hara yang diserap akar.

Unsur nitrogen yang terdapat dalam bahan organik mampu diserap dengan baik oleh tanaman, sehingga berpengaruh terhadap penambahan jumlah helai daun serta proses fotosintesis tanaman.Menurut Sudartiningsih dkk. (2002), nitrogen merupakan penyusun dari semua protein dan asam nukleat.Tanaman yang cukup mendapat suplai $\mathrm{N}$ akan membentuk helai daun yang luas dengan kandungan klorofil yang tinggi, sehingga tanaman dapat menghasilkan asimilat dalam jumlah cukup untuk menopang pertumbuhan vegetatifnya (Wijaya, 2008).

\section{Laju Pertumbuhan Daun}

Dari hasil analisa sidik ragam pemberian perlakuan bahan organik ternyata memberikan pengaruh yang nyataterhadap laju pertumbuhan daun bawang merah. Dapat dilihat bahwa nilai terbesar rerata laju pertumbuhan daun bawang merah terdapat pada perlakuan Tanpa Rumput Laut + Tanpa Kompos Azolla dan terendah ada pada perlakuan Rumput Laut 1000ppm + Tanpa Kompos Azolla (Tabel 2). 
Tabel 2. Rerata laju pertumbuhan daun bawang merah (helai/minggu) setelah diberi perlakuan pemberian bahan organik (rumput laut dan kompos Azolla).

\begin{tabular}{lc}
\multicolumn{1}{c}{ Perlakuan } & Rerata \\
\hline Tanpa Rumput Laut + Tanpa Kompos Azolla & 2,8325 a \\
Tanpa Rumput Laut + Kompos Azolla & 2,8023 a \\
Rumput Laut 1000ppm + Kompos Azolla & 2,7826 a \\
Rumput Laut 2000ppm + Kompos Azolla & $2,6251 \mathrm{ab}$ \\
Rumput Laut 2000ppm + Tanpa Kompos Azolla & $2,4309 \mathrm{ab}$ \\
Rumput Laut 1000ppm + Tanpa Kompos Azolla & $2,0295 \mathrm{~b}$ \\
\hline
\end{tabular}

Keterangan: Nilai Rerata yang diikuti huruf yang sama pada kolom yang sama menunjukkan tidak berbeda nyata menurut DMRT $5 \%$.

Pada penelitian ini diperoleh bahwa perlakuan kontrol lebih baik daripada perlakuan pemberian bahan organik dalam hal laju pertumbuhan daun. Hal ini dimungkinkan karena pemberian bahan organik digunakan oleh tanaman untuk meningkatkan jumlah daun terlebih dahulu, namun dalam hal penambahan daun tidak terlalu signifikan.

Walaupun begitu perlakuan pemberian bahan organik menunjukkan pertumbuhan yang lebih baik daripada kontrol/tanpa perlakuan, menurut Djuarnani dkk (2005) dosis bahan organik yang sesuai akan mempermudah tanaman untuk menyerap nutrisi yang terkandung di dalamnya untuk pertumbuhannya. Nutrisi yang diserap akan terakumulasi dibagian meristem daun. Dengan semakin banyak jumlah daun dan panjang daun, maka proses fotosintesis yang terjadi akan menjadi lebih baik.

\section{Jumlah Umbi}

Dari hasil analisa sidik ragam pemberian perlakuan bahan organik ternyata tidak memberikan pengaruh yang nyata terhadap jumlah umbi bawang merah, dapat dilihat pada Tabel 3.

Tabel 3. Rerata jumlah umbi bawang merah setelah diberi perlakuan pemberian bahan organik (rumput laut dan kompos Azolla).

\begin{tabular}{lr}
\multicolumn{1}{c}{ Perlakuan } & Rerata \\
\hline Rumput Laut 1000ppm + Tanpa Kompos Azolla & $7,0667 \mathrm{a}$ \\
Rumput Laut 2000ppm + Kompos Azolla & $6,8 \mathrm{a}$ \\
Rumput Laut 2000ppm + Tanpa Kompos Azolla & $6,4667 \mathrm{a}$ \\
Tanpa Rumput Laut + Kompos Azolla & $6,4667 \mathrm{a}$ \\
Tanpa Rumput Laut + Tanpa Kompos Azolla & $6,2 \mathrm{a}$ \\
Rumput Laut 1000ppm + Kompos Azolla & $5,8 \mathrm{a}$ \\
\hline Keterangan: Nilai Rerata yang diikuti huruf yang sama pada kolom yang sama menunjukkan \\
\end{tabular}


Bahan organik merupakan faktor yang mempengaruhi jumlah anakan dan jumlah umbi tanaman bawang merah karena akanmenjadikan tanah lebih porous. Tanah yang porous inilah yang mudah ditembus akar sehingga umbi yang terbentuk lebih besar dan lebih banyak (Gardner dkk., 1991; Sudiarso, 2007).

Dari penelitian yang dilakukan, diperoleh bahwa jumlah umbi dari perlakuan pemberian bahan organic dan kontrol tidak menunjukkan perbedaan. Hal ini mungkin disebabkan karena tanaman lamban menyerap beberapa unsur hara yang terkandung di dalam bahan organik, karena proses dekomposisi yang membutuhkan waktu yang lama. Selain itu diduga karena energi dari karbohidrat yang digunakan untuk pembelahan dan pembesaran serta diferensiasi sel yang memacu pada pembentukan organ tanaman yaitu anakan yang berupa tunas-tunas baru kurang memenuhi kebutuhan tanaman pada saat tumbuh dan berkembang.

\section{Diameter Umbi}

Dari hasil analisa sidik ragam pemberian perlakuan bahan organik ternyata memberikan pengaruh yang nyata terhadap diameter umbi bawang merah. Dapat dilihat bahwa nilai terbesar rerata diameter umbi bawang merah terdapat pada perlakuan Rumput Laut 2000ppm + Kompos Azolla dan terendah ada pada perlakuan Tanpa Rumput Laut + Tanpa Kompos Azolla (Tabel 4).

Tabel 4. Rerata diameter umbi bawang merah $(\mathrm{cm})$ setelah diberi perlakuan pemberian bahan organik (rumput laut dan kompos Azolla).

\begin{tabular}{lc}
\multicolumn{1}{c}{ Perlakuan } & Rerata \\
\hline Rumput Laut 2000ppm + Kompos Azolla & $2,6354 \mathrm{a}$ \\
Rumput Laut 1000ppm + Kompos Azolla & $2,5566 \mathrm{a}$ \\
Rumput Laut 1000ppm + Tanpa Kompos Azolla & $2,4582 \mathrm{ab}$ \\
Rumput Laut 2000ppm + Tanpa Kompos Azolla & $2,3779 \mathrm{ab}$ \\
Tanpa Rumput Laut + Kompos Azolla & $2,1891 \mathrm{ab}$ \\
Tanpa Rumput Laut + Tanpa Kompos Azolla & $1,9856 \mathrm{~b}$ \\
\hline Keterangan: Nilai Rerata yang diikuti huruf yang sama pada kolom yang sama menunjukkan \\
\end{tabular}

Pembentukan umbi pada tanaman bawang merah dipengaruhi oleh berbagai faktor, salah satu faktor lingkungan yang mempengaruhi adalah sumber hara yang diserap oleh tanaman. Unsur $\mathrm{P}$ yang diserap akan mendukung pembentukan sel-sel baru pada mata tunas, sehingga dapat meningkatkan pembelahan sel pada umbi dan dapat meningkatkan diameter umbi.

Menurut Munawar (2011) $\mathrm{P}$ berperan dalam pembelahan sel melalui peranan

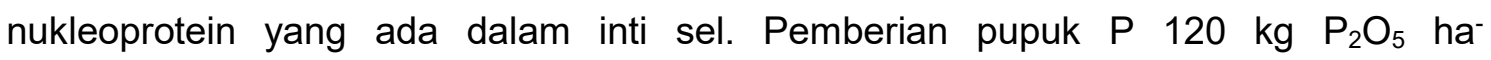


${ }^{1}$ memberikan hasl diameter umbi yang paling tinggi yaitu $10,01 \mathrm{~mm}$ dan meningkat secara nyata sebesar $26,23 \%$ dibandingkan tanpa pemberian pupuk P. Hal ini disebabkan $P$ berperan dalam transfer fotosintat dari ke seluruh organ tanaman termasuk umbi. Peningkatan energi dalam bentuk ATP dan ADP sehingga dapat meningkatkan translokasi fotosintat ke bagian umbi sehingga umbi tanaman meningkat.

\section{Bobot Segar Umbi}

Dari hasil analisa sidik ragam pemberian perlakuan bahan organik ternyata tidak memberikan pengaruh yang nyata terhadap bobot segar umbi bawang merah, dapat dilihat pada tabel 5 .

Tabel 5. Rerata bobot segar umbi bawang merah $(\mathrm{g})$ setelah diberi perlakuan pemberian bahan organik (rumput laut dan kompos Azolla).

\begin{tabular}{lr}
\hline \multicolumn{1}{c}{ Perlakuan } & \multicolumn{1}{c}{ Rerata } \\
\hline Rumput Laut 2000ppm + Kompos Azolla & $0,28467 \mathrm{a}$ \\
Rumput Laut 1000ppm + Kompos Azolla & $0,24533 \mathrm{a}$ \\
Rumput Laut 2000ppm + Tanpa Kompos Azolla & $0,244 \mathrm{a}$ \\
Tanpa Rumput Laut + Tanpa Kompos Azolla & $0,244 \mathrm{a}$ \\
Tanpa Rumput Laut + Kompos Azolla & $0,20667 \mathrm{a}$ \\
Rumput Laut 1000ppm + Tanpa Kompos Azolla & $0,19867 \mathrm{a}$ \\
\hline
\end{tabular}

Keterangan: Nilai Rerata yang diikuti huruf yang sama pada kolom yang sama menunjukkan tidak berbeda nyata menurut DMRT $5 \%$.

Bahan organik merupakan faktor yang mempengaruhi jumlah umbi, diameter hingga bobot segar tanaman bawang merah.Pada penelitian kali ini, bobot segar umbi bawang merah tidak menunjukkan adanya perbedaan yang nyata antar perlakuan. Hal ini diduga karena asimilat yang dihasilkan dari daun tidak terdistribusi dengan sempurna ke umbi. Walaupun pada beberapa unsur yang terkandung pada pupuk organik yang diberikan seharusnya mampu digunakan tanaman untuk menigkatkan hasil dari tanaman.

\section{Indeks Panen}

Dari hasil analisa sidik ragam pemberian perlakuan bahan organik ternyata memberikan pengaruh yang nyata terhadap indeks panen bawang merah. Dapat dilihat bahwa nilai terbesar rerata indeks panen bawang merah terdapat pada perlakuan Rumput Laut 1000ppm + Kompos Azolla dan terendah ada pada perlakuan Rumput Laut 2000ppm + Kompos Azolla (Tabel 6). 
Tabel 6. Rerata indeks panen bawang merah (\%) setelah diberi perlakuan pemberian bahan organik (rumput laut dan kompos Azolla).

\begin{tabular}{lc}
\multicolumn{1}{c}{ Perlakuan } & Rerata \\
\hline Rumput Laut 1000ppm + Kompos Azolla & $2,7482 \mathrm{a}$ \\
Tanpa Rumput Laut + Tanpa Kompos Azolla & $2,6371 \mathrm{ab}$ \\
Tanpa Rumput Laut + Kompos Azolla & $2,4861 \mathrm{ab}$ \\
Rumput Laut 1000ppm + Tanpa Kompos Azolla & $2,3425 \mathrm{ab}$ \\
Rumput Laut 2000ppm + Tanpa Kompos Azolla & $2,2932 \mathrm{~b}$ \\
Rumput Laut 2000ppm + Kompos Azolla & $2,2453 \mathrm{~b}$ \\
\hline
\end{tabular}

Keterangan: Nilai Rerata yang diikuti huruf yang sama pada kolom yang sama menunjukkan tidak berbeda nyata menurut DMRT $5 \%$.

Indeks panen menunjukkan distribusi bahan kering dalam tanaman yang menunjukkan perimbangan bobot bahan kering yang bernilai ekonomis dengan total bobot bahan kering tanaman pada saat panen.

Nilai indeks panen yang diperoleh pad penelitian ini cenderung tinggi, dimana yang tertinggi ada pada perlakuan Rumput Laut 1000ppm + Kompos Azolla dan yang terendah Rumput Laut 2000ppm + Kompos Azolla.

Nilai indeks panen tinggi menunjukkan varietas mampu mendistribusikan asimilat lebih banyak ke dalam polong.Hal tersebut berkaitan dengan pengaruh genetik dari masing-masing varietas. Namun secara umum indeks panen dari hasil penelitian lebih dari 0,7 yang meunjukkan indeks panen terbaik bagi tanaman. Menurut Brewster (1994), nilai indeks panen yang baik untuk tanaman bawang merah tidak kurang dari 0,7 . Hal tersebut menunjukkan bahwa fotosintat lebih banyak digunakan untuk disimpan didalam umbi daripada untuk pertumbuhan dan perkembangan organ lainnya (Hamdani, 2008).

\section{KESIMPULAN}

Perlakuan penambahan bahan organik (rumput laut dan Azolla) dapat meningkatkan beberapa variabel diantaranya laju pertumbuhan tinggi tanaman, laju pertumbuhan daun dan diameter umbi, dibandingkan perlakuan tanpa bahan organik.

\section{DAFTAR PUSTAKA}

Anonim. 2018. 10 Manfaat Bawang Merah Bagi Kesehatan. <https://doktersehat.com/manfaat-super-bawang-merah/>diunduh pada tanggal 26 Desember 2018.

Basmal, J. 2009. Prospek Pemanfaatan Rumput Laut Sebagai Bahan Pupuk Organik. Squalen 4(1):1-8.

Begananda, B. (2019). Aplikasi Mikoriza dan Azolla pada Budidaya Bawang Merah di Lahan Marjinal. Prosiding, 8(1). 
Brewster, J.L. 1994. Onions and Other Vegetable Alliums. CAB International. Wallingford. UK. pp.236.

Djuarnani, N., Kritian dan Budi. 2005. Cara Cepat Membuat Kompos. AgroMedia Pustaka. Jakarta.

Gardner, F.P., R. B. Pearce dan R. L. Mitchell. 1991. Crops Physiology: Field Crops Physiology. UI Press. Jakarta.

Hamdani, J.S. 2008. Pertumbuhan dan Hasil Bawang Merah Kultivar Kuning pada Status Hara P Total Tanah dan Dosis Fosfat yang Berbeda. Jurnal Agrikultura, 19 (1) : 42-49.

Havlin, J.L., J.P. Beaton., S.L. Tisdale dan W.L. Nelson. 1999. Soil Fertility and Fertilizer. An Introduction to Nutrient Management. Sixth ed. Prentice Hall. New Jersey.

Latarang, B dan Syakur. 2006. Pertumbuhan dan Hasil Bawang Merah (Allium ascalonicum L.) pada Berbagai Dosis Pupuk Kandang di Daerah Palu Utara. Agroland 13 (3):265-269.

Munawar, A. 2011. Kesuburan Tanah dan Nutrisi Tanaman. IPB Press. Bogor.

Rokhminarsi, E., dan Utami, D. S. (2019). Efektivitas Pupuk Hayati Mikoriza Berbasis Azolla (Mikola) pada Tanaman Bawang Merah (Effectiveness of Biofertilizer Mycorrhiza Based Azolla (Mikola) on Shallot). Jurnal Hortikultura, 29(1), 45-52.

Rosmarkam, A. dan N.W. Yuwono. 2002. IImu Kesuburan Tanah. Kanisius. Yogyakarta.

Samadi dan Cahyono, 2005, Intensifikasi Usaha Tanai Bawang Merah. Penerbit Kanisius, Yogyakarta, hal : $15-24$

Sudartiningsih, D, S.R Utami dan B.prasetya. 2002. Pengaruh Pemberian Pupuk Urea dan pupuk "Organik Diperkaya terhadap Ketersediaan dan Serapan N serta Produksi Cabai Besar (Capsicum annum L.) pada InceptisolKarangploso Malang. Agrivita 24(1): 63-69.

Sudiarso. 2007. Pupuk organik dalam Sistem Pertanian Berkelanjutan. FP UB. Malang.

Suryanto. 2017. Pengaruh Dosis Pupuk Kompos Azolla dan Npk Hidrocarate terhadap Hasil Bawang Merah (Allium ascalonikum). Jurnal Agrohita1(2):58-63

Susanti, A.A., B. Waryanto, R. Widaningsih, dan M. Chafid. 2017. Outlook Tanaman Pangan dan Hortikultura. Pusat Data dan Sistem Informasi Pertanian, Sekretariat Jenderal Kementerian Pertanian. <http://epublikasi.setjen.pertanian.go.id/ epublikasi/outlook/2017/Outlook\%20TPHORTI\%202017/.>. Diakses pada 13 Mei 2019 .

Widawati, S, Suliasih dan Syaifudin 2002, Pengaruh Introduksi Kompos Plus terhadap Produksi Bobot Kering Daun Kumis Kucing (Orthosiphon Aristatus BI. Miq) pada Tiga Macam Media Tanah. J. Biol. Indonesia, 3 (3): 245-253.

Wijaya, K. A. 2008. Nutrisi Tanaman. Prestasi Pustaka Publisher. Jakarta. 